p-ISSN 0044-1600

e-ISSN 2392-3458

Zagadnienia Ekonomiki Rolnej

www.zer.waw.pl

$3(352) 2017,19-40$

ZBIGNIEW GOEAŚ

DOI: $10.30858 /$ zer/83030

University of Life Sciences

Poznań

\title{
DETERMINANTS OF MILK PRODUCTION PROFITABILITY OF DAIRY FARMS IN THE EU MEMBER STATES
}

\begin{abstract}
The article presents analysis of determinants of milk production profit margin on dairy farms. The research focuses on farms in the EU Member States and is based on statistical data coming from the European Commission's Dairy Farm Reports for 2007-2013. Milk production margin was analysed on the basis of detailed accounts of income and expenses that allowed to conduct multifaceted evaluation of farms' ability to generate income from milk production measured by gross and net margin. Furthermore, the panel data regressions models were applied in order to identify intensity and direction of chosen technological and economic, price and cost characteristics' influence on milk production margin. The size of forage area, herd size, cows' milk yield, milk prices and energy and salary costs should be considered, in the light of panel regression parameters, as most influential factors.
\end{abstract}

Keywords: profit margin of milk production, dairy farms, the EU countries, panel data regression models.

JEL codes: Q11, Q14, C23.

\section{Introduction}

The profitability of farms, understood as their ability to generate profits, is determined by a number of financial, property and macroeconomic factors, as well as by structural sectoral determinants and their individual technological and economic characteristics. The study on the factors affecting the margin of farms is important for many reasons. Firstly, it constitutes a basis for ex-post assessment of the rationality of agricultural producers' decisions, secondly, is an important 
guideline to improve agricultural policy tools, thirdly, it is important for maintaining the continuity of pursued agricultural activity. It is also worth stressing that the accumulation of profit is the primary and most important source of capital growth and the margin level is a synthetic indicator of the financial situation, which fundamentally affects the assessment of the farms' competitive capacity and thus - their capacity to continue their operations and development prospects.

The objective of the studies presented in this paper is to analyse the diversification and determinants of the production margin in specialised dairy farms of the European Union countries. The study on the production margin of this type of farms, in addition to educational and utilitarian values, is justified by the following reasons:

- income from milk production in the EU-28 exceeding EUR 51 billion accounts for around $32 \%$ of the total livestock production income and around $14 \%$ of total agricultural production income ${ }^{1}$;

- specialised milk production is conducted in the EU by more than 572 thousand farms, i.e. 5.3\% of all farms (Farm structure survey, 2013);

- specialised dairy farms pursue their activity on the area of approx. 20 million ha, i.e. around $11 \%$ of agricultural land used in the EU (Farm structure..., 2013);

- specialised dairy farms employ nearly one million people (AWU), i.e. around $11 \%$ of total employment in agriculture (Farm structure ..., 2013);

- economic and financial situation of specialised dairy farms in the individual EU countries is strongly diversified and generally unstable.

\section{Source materials and research methods}

The source material for the studies consisted of periodical reports on economic and financial situation of the dairy farm sector in the EU - EU Dairy Farms Report (EU Dairy..., 2016). These reports contain detailed information presented as technological and economic as well as financial parameters of specialised dairy farms, which is collected as part of the accounting system - Farm Accountancy Data Network. The analysis of the entire EU dairy sector used the statistical data for the years 2007-2013, while the comparative analysis of the EU countries was limited to the last published complete data for 20132. In both analytical overviews, farms were analysed in the context of their production capacity and milk production margin. The following factors were adopted as major determinants of production capacity: forage area and its productivity, size of herds, cows' milk yield and employment. In turn, the milk production margin account has been used to analyse the determinants of net and gross margin level,

\footnotetext{
${ }^{1}$ Average values from the years 2007-2016 estimated based on: Economic Accounts for Agriculture, http:// appsso.eurostat.ec.europa.eu, accessed on: 15.04.2017.

${ }^{2}$ Currently, the full data in the EU countries is available only until 2013 while for 2014 and 2015 only preliminary results for the EU as a whole were published.
} 
resulting from differences in the level of milk prices and from differences in the level of unit direct costs, farming overheads, depreciation costs and costs of internal factors.

In addition, the paper attempts to model the variability of the margin level. Panel regression methods were applied to determine the factors affecting the milk production margin (net and gross). These methods allow to carry out a simultaneous analysis of a phenomenon in many dimensions (e.g. time, object, space), to identify specificity of the analysed objects, increase the heterogeneity of the studied objects, provide greater efficiency of estimates, and allow to identify the impact of unobservable variables or effects (Kufel, 2007; Wooldridge, 2002; Greene, 2003; Verbeek, 2004; Baltagi, 2005).

In constructing the panel models, two types of estimators have been used fixed effects estimator and random effects estimator. The validity of applying panel regression has been verified based on the Breusch-Pagan test, while the analytical form of the model, i.e. fixed or random effects, has been selected based on the Hausman test (Kufel, 2007; Czyżewski and Staniszewski, 2016; Gruszczyński, 2002; Geise, 2013; Franc-Dąbrowska, 2009).

\section{Basic economic and technical parameters and milk production margin in the $\mathrm{EU}$ countries in the years 2007-2013}

Table 1 shows average levels of the main characteristics of EU farms specialised in the milk production in the years 2007-2013. Their analysis shows that in general the EU dairy farms recorded a relatively marked increase in the size of cow herds, forage area and milk production. Over the analysed period, the average number of cows increased, on an annual average, by $2.9 \%$ and in $2013(28 \mathrm{LU})$, in relation to $2007(23.1 \mathrm{LU})$, it was higher by more than $20 \%$. The annual average growth rate $(2.8 \%)$ of forage area was comparable to the growth rate of the number of cows. Consequently, the number of cows per unit of forage area, and thus forage area per 1 cow were virtually constant over the analysed period (1.0-1.1 LU/ha and 0.94-0.97 ha/LU). The presented data (Table 1) also shows that development of production capacity of the dairy farm sector was strongly linked with an increase in their productivity. Over the analysed period, a significant increase was recorded in the average milk yield (from around 6,500 to more than 6,800 kg), forage area productivity (from 6.6 to more than 7 tonnes of milk/ha) and, most importantly, labour productivity (from about 80 to more than 110 tonnes of milk/AWU). It is worth stressing that while milk yield and forage area productivity grew at a comparable rate (0.8-0.9\%), labour productivity increased by as much as $5.8 \%$ on an annual average. Such a significant increase in labour productivity resulted mainly from increased milk production volume, and, although to a relatively lower extent, from reduced labour inputs. 
Table 1

Basic technological and economic characteristics of the dairy farm sector in the European Union in the years 2007-2013

\begin{tabular}{|c|c|c|c|c|c|c|c|c|}
\hline Specification & 2007 & 2008 & 2009 & 2010 & 2011 & 2012 & 2013 & $\Delta^{1}$ \\
\hline Number of cows (LU) & 23.1 & 23.7 & 26.5 & 29.4 & 29.6 & 28.0 & 27.6 & 2.9 \\
\hline Forage area (ha) & 22.3 & 22.9 & 24.8 & 28.4 & 28.6 & 26.8 & 26.3 & 2.8 \\
\hline Total milk production & 150 & 154 & 174 & 199 & 205 & 191 & 188 & 3.8 \\
\hline Number of employees (AWU) & 1.9 & 1.9 & 1.9 & 1.8 & 1.8 & 1.7 & 1.7 & -2.0 \\
\hline $\begin{array}{l}\text { Milk production } \\
\text { (tonnes of milk/ha of forage area) }\end{array}$ & 6.6 & 6.6 & 6.9 & 6.9 & 7.0 & 7.0 & 7.1 & 0.9 \\
\hline Milk production & 6498 & 6480 & 6566 & 6770 & 6918 & 6825 & 6819 & 0.8 \\
\hline $\begin{array}{l}\text { Labour productivity } \\
\text { ( } \mathrm{t} \text { of milk/AWU) }\end{array}$ & 78.9 & 81.1 & 91.6 & 110.6 & 113.9 & 112.4 & 110.6 & 5.8 \\
\hline
\end{tabular}

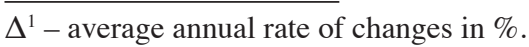

Source: EU Dairy Farms Report based on 2013 FADN data (2016).

However, over the analysed period the increase in the production capacity and productivity of dairy farms did not translate into positive changes in the margin measured by gross and net profit (Table 2). Although in the years 2007-2013, the milk production margin was subject to multidirectional changes, it generally followed a negative trend, mainly as a result of the much faster rise in production costs rather than in milk prices. Despite a significant decline in 2009 , milk prices in the EU, on an annual average, rose by approx. $2 \%$ and in 2013 reached their peak value in the analysed period (EUR 379.8/tonne). However, the growth rate of unit direct costs (on average, by $4.5 \%$ ) and farming overheads (on average, $3 \%$ ) was much higher, which translated into a nearly $4 \%$ growth in operating costs, on an annual average. This was caused largely by a rise in the costs of feed (especially purchased feed) and energy costs. Despite the relatively constant share of total feed in direct costs (about 80\%), their level per unit of production increased, on an annual average, by $4.9 \%$, and that of purchased feed even by $6 \%$, i.e. respectively, by 2.5 -and 3 times faster than the milk prices. In turn, given the energy costs, we may observe that they also increasingly negatively affected the milk production margin. In the analysed years, the energy costs per tonne of milk were rising, on an annual average, by almost $5 \%$ and their share in farming overheads increased from approx. $23 \%$ to almost $27 \%$. The trends resulted in a quite strong variability of the average gross margin with and without aid. Over the analysed period, the gross margin level ranged from EUR 141.7-143.9 (2007) to EUR 89.3-91.5 per tonne (2009). In addition, in the light of the growth rate indexes, the changes in the gross margin outlined a not too strong, but negative trend in the changes. In the years 2007-2013, unit gross profit (EUR/tonne) decreased, on an annual average, by $0.9 \%$ (without aid) and $0.7 \%$ (with aid). 
Table 2

Milk prices, costs and gross and net milk production margin in the European Union (EU-28) in the years 2007-2013 (EUR/t)

\begin{tabular}{|c|c|c|c|c|c|c|c|c|}
\hline Specification & 2007 & 2008 & 2009 & 2010 & 2011 & 2012 & 2013 & $\Delta^{1}$ \\
\hline \multicolumn{9}{|c|}{ Income $(\mathrm{EUR} / \mathrm{t})$} \\
\hline Basic milk price & 337,2 & 338,1 & 279,4 & 321.8 & 384.5 & 341.0 & 379.8 & 2.0 \\
\hline Special aid & 0,1 & 0,1 & 0.1 & 1.0 & 1.0 & 1.0 & 1.1 & 45.3 \\
\hline National aid & 2,1 & 2,3 & 2.3 & 2.3 & 2.4 & 2.5 & 2.7 & 4.4 \\
\hline Milk price with aid & 339,4 & 340,5 & 340.5 & 325.1 & 351.9 & 344.6 & 383.5 & 2.1 \\
\hline \multicolumn{9}{|c|}{ Production costs (EUR/t) } \\
\hline Direct costs, including: & 117.9 & 129.2 & 114.2 & 120.9 & 134.1 & 147.9 & 153.2 & 4.5 \\
\hline - total feed & 93.3 & 103.2 & 89.9 & 95.0 & 107.1 & 119.5 & 124.3 & 4.9 \\
\hline - home-grown feed & 29.5 & 31.9 & 27.7 & 28.5 & 30.8 & 33.5 & 34.1 & 2.4 \\
\hline - purchased feed & 63.8 & 71.3 & 62.2 & 66.5 & 76.4 & 86.0 & 90.3 & 6.0 \\
\hline Farming overheads, including: & 77.6 & 82.9 & 75.8 & 81.6 & 85.5 & 86.6 & 92.7 & 3.0 \\
\hline - machinery and building upkeep & 19.2 & 20.2 & 17.9 & 19.7 & 19.9 & 19.5 & 21.2 & 1.7 \\
\hline - energy (fuel, electricity) & 18.4 & 20.6 & 18.0 & 20.2 & 22.4 & 23.1 & 24.4 & 4.8 \\
\hline - costs of contract work & 16.4 & 18.0 & 16.6 & 17.1 & 17.9 & 18.7 & 20.3 & 3.6 \\
\hline Operating costs & 195.5 & 212.1 & 190.0 & 202.5 & 219.6 & 234.5 & 245.9 & 3.9 \\
\hline Gross profit & 141.7 & 126.0 & 89.3 & 119.3 & 128.9 & 106.5 & 133.9 & -0.9 \\
\hline Gross profit with aid & 143.9 & 128.4 & 91.5 & 122.6 & 132.3 & 110.0 & 137.6 & -0.7 \\
\hline Depreciation & 44.8 & 47.4 & 45.9 & 48.0 & 47.7 & 48.5 & 51.9 & 2.5 \\
\hline Costs of external factors & 39.8 & 42.5 & 40.7 & 41.2 & 41.6 & 40.9 & 42.8 & 1.2 \\
\hline - salaries & 13.9 & 14.6 & 14.8 & 15.4 & 16.1 & 15.8 & 17.3 & 3.8 \\
\hline - rent & 13.0 & 12.5 & 12.4 & 12.8 & 12.8 & 12.8 & 13.6 & 0.7 \\
\hline - interest & 12.9 & 15.4 & 13.5 & 13.0 & 12.7 & 12.3 & 11.9 & -1.4 \\
\hline Net profit & 57.1 & 36.1 & 2.8 & 30.0 & 39.6 & 17.1 & 39.2 & -6.1 \\
\hline Net profit with aid & 59.3 & 38.5 & 5.0 & 33.3 & 43.0 & 20.6 & 42.9 & -5.2 \\
\hline
\end{tabular}

$\Delta^{1}$ - average annual rate of changes in $\%$.

Source: EU Dairy Farms Report based on 2013 FADN data (2016). 


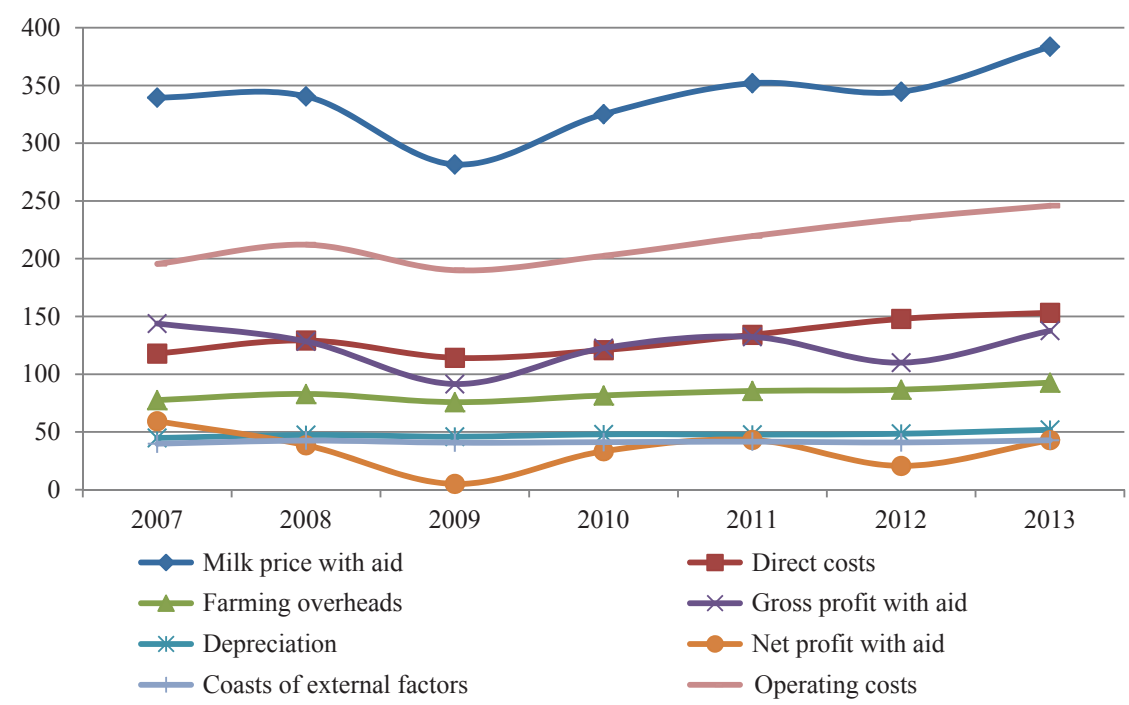

Fig. 1. Changes in prices, production costs and milk production margin in the EU in the years 2007-2013 (EUR/t).

Source: own study.

In turn, taking into account other costs of the margin account, we may notice that their growth with the decreasing gross margin in general led to a significant reduction in net profit. Over the analysed period, the depreciation costs per tonne of milk rose, on an annual average, by $2.5 \%$, and the costs of external factors - by $1.2 \%$ (including the costs of salaries by as much as $3.8 \%$ ). Those trends led to a strong reduction of the net margin. With the great variability in the individual years of the analysed period, on an annual average, unit net profit without aid decreased by $6.1 \%$, and with aid by $5.2 \%$.

\section{Differentiation of the basic technological and economic parameters and the milk production margin in the EU countries}

The above presented technological and economic characteristics of the sector of farms specialised in the milk production reflect their average level in the EU, and thus do not reflect the enormous differences that exist among the individual countries. These differences have a number of sources and apart from the historical and socio-political context they result largely from natural resources held (climate, natural pastures), state of technical infrastructure, technological advancement, production scale and market orientation (Parzonko, 2013; Ziętara, 2003).

The degree of diversification among the basic technological and economic parameters of dairy farms in the EU countries is reflected by the data contained in Table 3 and in Figures 2-5. On a basis of the latest complete data from 2013 
and the variability index, it can be said that they differ particularly strongly in terms of the forage area $(\mathrm{V}=182.5 \%)$, labour resources $(\mathrm{V}=168.6 \%)$, forage area productivity $(\mathrm{V}=133.1 \%)$, strongly in terms of the milk production volume $(\mathrm{V}=92.3 \%)$, number of cows $(\mathrm{V}=90,3 \%)$ and labour productivity $(\mathrm{V}=81.9 \%)$, while relatively less in terms of the share of rented land $(\mathrm{V}=40.8 \%)$ and cows' milk yield $(\mathrm{V}=21.5 \%)$.

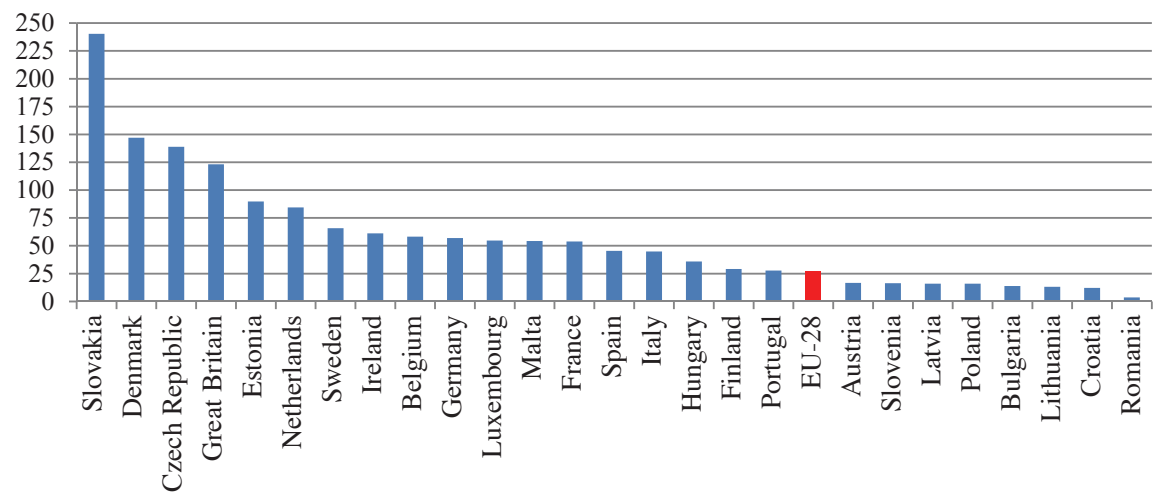

Fig. 2. Average number of cows (LU/farm) in dairy farms of the EU countries in 2013. Source: own study.

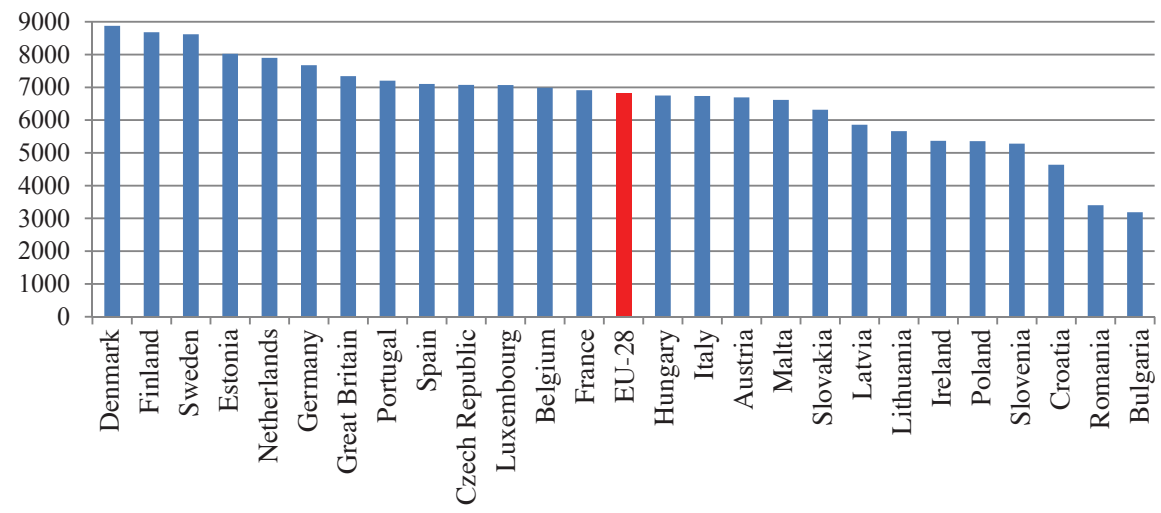

Fig. 3. Average cows' milk yield (kg) in dairy farms of the EU countries in 2013.

Source: own study. 


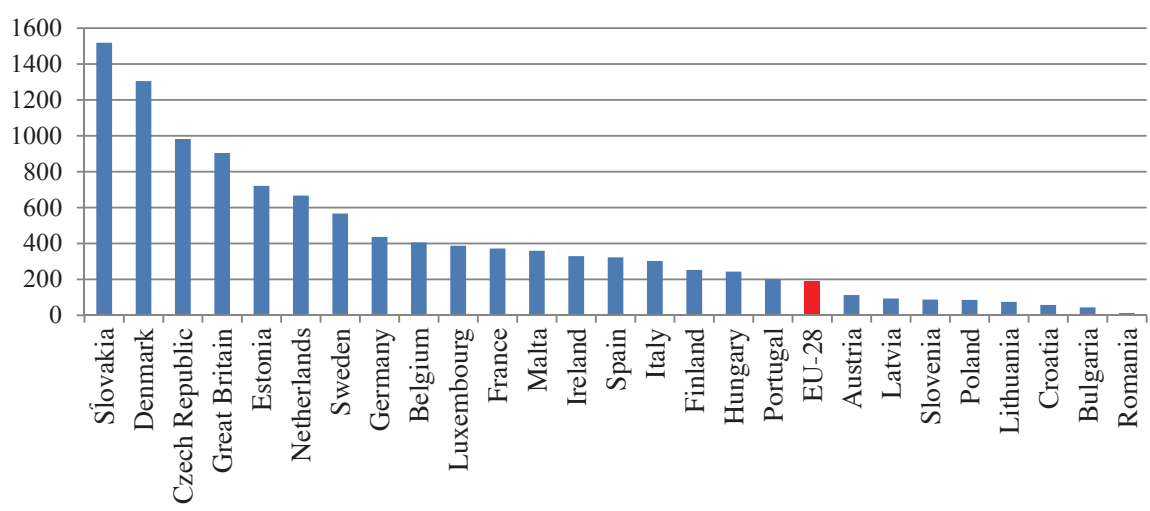

Fig. 4. Average milk production (tonnes/farm) in dairy farms of the EU countries in 2013. Source: own study.

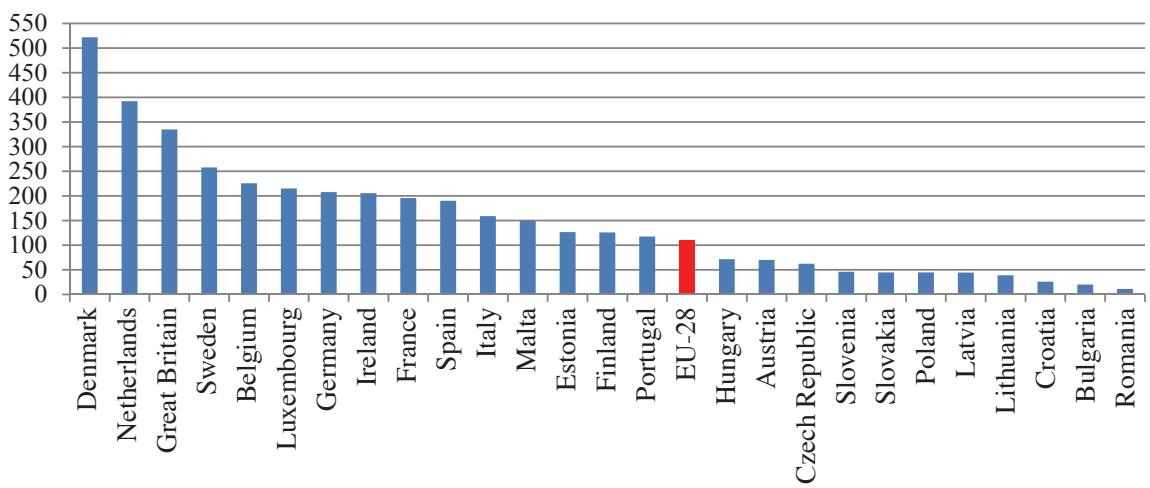

Fig. 5. Average labour productivity (t/AWU) in dairy farms of the EU countries in 2013. Source: own study.

In terms of the average number of cows per farm, the largest production potential is attributed to farms in Slovakia (240 LU), Denmark (147 LU), the Czech Republic (139 LU) and the United Kingdom (123 LU), where the size of herds was larger than average by as many as 4.5-8.7 times. In turn, the lowest degree of herd concentration was characteristic mostly of farms in Romania (3.6 LU), as well as in Croatia (12.2 LU), Lithuania (13.1 LU) and Latvia (15.9 LU), Poland (15.9 LU), Slovenia (16.4) and Austria (16.7 LU). In farms in these countries, the size of cow herds was lower than, on average, in the EU by $47-80 \%$.

In general, dairy farms are largely differentiated by the size of the forage area (ha) and milk production (t) and the number of the employed (AWU). The correlation between the number of cows and the forage area, milk production and labour inputs is, in fact, strong and amounts to, respectively: $\mathrm{R}=0.85 ; \mathrm{R}=0.98$; $\mathrm{R}=0.79$. However, much weaker relations are noticeable in the case of comparing the stocking density of cows with the basic productivity indices. The coef- 
ficients of correlation between the number of cows and the forage area productivity $(\mathrm{R}=-0,003)$, milk yield $(\mathrm{R}=0.424)$ and labour productivity $(\mathrm{R}=0.405)$ are significantly lower or even statistically insignificant.

Table 3

Basic technological and economic characteristics of farms specialised in the milk production in the European Union countries in 2013

\begin{tabular}{|c|c|c|c|c|c|c|c|}
\hline Countries & $\begin{array}{l}\text { Number } \\
\text { of cows } \\
\text { (LU) }\end{array}$ & $\begin{array}{c}\text { Forage } \\
\text { area } \\
\text { (ha) }\end{array}$ & $\begin{array}{l}\text { Milk } \\
\text { production } \\
\text { (t/ farm) }\end{array}$ & $\begin{array}{l}\text { Number } \\
\text { of the } \\
\text { employed } \\
\text { (AWU) }\end{array}$ & $\begin{array}{c}\text { Milk } \\
\text { production } \\
\text { (t/ha of } \\
\text { forage area) }\end{array}$ & $\begin{array}{l}\text { Milk } \\
\text { yield } \\
\text { (kg per } \\
\text { cow) } \\
\end{array}$ & $\begin{array}{l}\text { Labour } \\
\text { productivity } \\
\text { (t/AWU) }\end{array}$ \\
\hline Belgium & 58.2 & 46.4 & 406 & 1.8 & 8.8 & 6,989 & 225.6 \\
\hline Denmark & 147.0 & 105.5 & 1,305 & 2.5 & 12.2 & 8,879 & 522.0 \\
\hline Germany & 56.9 & 52.4 & 436 & 2.1 & 8.3 & 7,674 & 207.6 \\
\hline Spain & 45.4 & 24.4 & 323 & 1.7 & 12.5 & 7,102 & 190.0 \\
\hline France & 53.8 & 70.9 & 372 & 1.9 & 5.2 & 6,911 & 195.8 \\
\hline Ireland & 61.2 & 56.1 & 329 & 1.6 & 5.9 & 5,369 & 205.6 \\
\hline Italy & 44.8 & 21.4 & 302 & 1.9 & 13.6 & 6,738 & 158.9 \\
\hline Luxembourg & 54.7 & 74.4 & 387 & 1.8 & 5.2 & 7,071 & 215.0 \\
\hline Netherlands & 84.5 & 48.5 & 667 & 1.7 & 13.8 & 7,900 & 392.4 \\
\hline Austria & 16.7 & 28.2 & 112 & 1.6 & 4.0 & 6,692 & 70.0 \\
\hline Portugal & 27.7 & 17.3 & 200 & 1.7 & 11.5 & 7,202 & 117.6 \\
\hline Finland & 29.1 & 37.7 & 252 & 2.0 & 6.7 & 8,683 & 126.0 \\
\hline Sweden & 65.8 & 90.6 & 567 & 2.2 & 6.3 & 8,619 & 257.7 \\
\hline United Kingdom & 123.2 & 103.6 & 904 & 2.7 & 8.7 & 7,341 & 334.8 \\
\hline Czech Republic & 138.9 & 257.6 & 982 & 15.8 & 3.8 & 7,073 & 62.2 \\
\hline Estonia & 89.8 & 177.7 & 721 & 5.7 & 4.1 & 8,026 & 126.5 \\
\hline Hungary & 35.9 & 44.0 & 243 & 3.4 & 5.3 & 6,749 & 71.5 \\
\hline Lithuania & 13.1 & 27.2 & 74 & 1.9 & 2.7 & 5,665 & 38.9 \\
\hline Latvia & 15.9 & 40.7 & 93 & 2.1 & 2.3 & 5,857 & 44.3 \\
\hline Malta & 54.2 & 3.9 & 359 & 2.4 & 66.8 & 6,619 & 149.6 \\
\hline Poland & 15.9 & 13.0 & 85 & 1.9 & 6.6 & 5,358 & 44.7 \\
\hline Slovakia & 240.4 & 791.9 & 1,519 & 33.9 & 1.9 & 6,318 & 44.8 \\
\hline Slovenia & 16.4 & 15.3 & 87 & 1.9 & 5.7 & 5,280 & 45.8 \\
\hline Bulgaria & 13.8 & 8.5 & 44 & 2.2 & 4.3 & 3,188 & 20.0 \\
\hline Romania & 3.6 & 2.6 & 12 & 1.1 & 3.6 & 3,405 & 10.9 \\
\hline Croatia & 12.2 & 10.4 & 57 & 2.2 & 5.4 & 4,638 & 25.9 \\
\hline $\mathrm{V}^{1}(\%)$ & 90.3 & 182.5 & 92.3 & 168.6 & 133.1 & 21.5 & 81.9 \\
\hline
\end{tabular}

Source: EU Dairy Farms Report based on 2013 FADN data (2016). 
The extremely high forage area productivity was obtained by farms in Malta $(66.8 \mathrm{t} / \mathrm{ha})$, and relatively high $(11.5-13.8 \mathrm{t} / \mathrm{ha})$, when compared to the EU average (7.1 t/ha) also by Danish, Spanish, Italian, Dutch and Portuguese farms. A common feature of farms in these countries is a relatively small forage area per cow which in Malta is only $0.07 \mathrm{ha} / \mathrm{LU}$, and in other countries $0.5-0.7 \mathrm{ha} / \mathrm{LU}$. Such ratios result from the cattle feeding system, largely based on purchased feed, which, with the large size of herds and their milk yield $(6,619-8,879 \mathrm{~kg})$ translates into high forage area productivity. In the vast majority of other countries (except Belgium, Germany and the United Kingdom), the forage area productivity was clearly lower than the average $(7.1 \mathrm{t} / \mathrm{ha})$ and was generally associated with the higher ratio of this area to the number of cows, with strongly diversified milk yield. The particularly low milk yield from 1 ha of forage area was recorded in Slovakia (1.9 t/ha), Lithuania (2.7 t/ha) and Latvia (2.3 t/ha). In these countries, the forage area per $1 \mathrm{cow}$ is, however, clearly larger (2.1-3.3 ha/LU) and results from the feeding system based mainly on home-grown feed. In addition, the low forage area productivity is in their case related to the lower than average cows' milk yield $(5,665-6,318 \mathrm{~kg})$.

As mentioned previously, dairy farms vary to the relatively lowest extent in terms of the cows' milk yield $(\mathrm{V}=21.5 \%)$. Nevertheless, clear differences are visible also in this regard, especially if we take into account the extreme values. Particularly positive results in these terms are recorded by farms in Denmark $(8,879 \mathrm{~kg})$, Finland $(8,683 \mathrm{~kg})$ and Sweden $(8,619 \mathrm{~kg})$, where milk yield was $26-30 \%$ higher than the average. The relatively high milk yield is also characteristic of farms in Estonia $(8,026 \mathrm{~kg})$, the Netherlands $(7,900 \mathrm{~kg})$ and Germany $(7,674 \mathrm{~kg})$, where the amount of milk obtained from 1 cow was $13-17 \%$ higher than the EU average. In turn, the poorest results were definitely obtained in Bulgaria $(3,188 \mathrm{~kg})$ and Romania $(3,405 \mathrm{~kg})$, where milk yield represented less than $50 \%$ of the EU average. The relatively low cows' milk yield is also characteristic of farms in Croatia, Slovenia, Poland and Ireland, where the amount of milk in $\mathrm{kg}$ obtained from 1 cow was $22-33 \%$ lower than the average.

Dairy farms in the EU countries strongly $(\mathrm{V}=81.9 \%)$ differ also in terms of labour productivity ( $\mathrm{t} / \mathrm{AWU}$ ). Its lowest level was recorded mainly in the new Member States (except for Estonia), especially in Croatia, Romania and Bulgaria, where the labour productivity was only $10-20 \%$ of the EU average. In this regard, farms in Lithuania, Latvia, Slovakia, Poland and Slovenia also come off negatively. In their case, labour productivity was lower than the average by as much as $60-65 \%$. Compared to farms of the new Member States, labour productivity in the old EU countries is strikingly different. In 2013 (except for Austria), labour productivity in those countries was significantly higher than the average, and in some countries even several-fold. A particularly high labour productivity ( $\mathrm{t} / \mathrm{AWU}$ ) is characteristic for Danish, Dutch and British farms, where the amount of milk per one annual work unit was, respectively: 552, 392 and 
335 tonnes. These values indicate that labour productivity in those countries is 3.0-4.7 times higher than the average. The high efficiency of labour resources was also recorded in Belgium and Sweden, where in relation to the average values, milk production in $\mathrm{t} / \mathrm{AWU}$ was higher by $104 \%$ and $133 \%$, respectively.

Table 4 shows the basic items in the milk production margin account in farms of the EU countries. The starting point of the presented account is income ${ }^{3}$ (EUR/t) from milk production, which, in the light of the variability index, generally did not show any significant differences $(\mathrm{V}=14.4 \%)$. However, given their average level in the EU which amounted to EUR 383/t (Table 2), they were lower in most countries (19). A relatively high income (EUR/t) from milk production was achieved by farms in Germany (EUR 400/t), Denmark (EUR 404/t), Sweden (EUR 419/t), the Netherlands (EUR 431/t) and Italy (EUR 449/t), and particularly high (higher than the average by 30-36\%) by farms in Malta (EUR 498/t) and Finland (EUR 524/t) ${ }^{4}$. The situation in this regard was much less favourable in most new EU countries, especially in Lithuania (EUR 305/t), Poland (EUR 308/t) and Romania (EUR 327/t), where milk prices with aid were lower than the average by about $20 \%$.

Direct unit cost $(\mathrm{V}=28.8 \%)$, determined mainly by the costs of feed $(\mathrm{V}=33.4 \%)$, diversify dairy farms in the EU countries more strongly than the milk prices. In addition, from the data contained in Table 4 it results basically that the rise in the total unit costs of feed entails a change in their structure to the benefit of the higher share of purchased feed. The highest direct costs $(E U R / t)$ were characteristic of farms in Malta (EUR 336/t), and their high level (EUR 185-193/t) has also been recorded in Sweden, Finland, Slovakia, Hungary and Spain. In those countries (except for Slovakia), the high total unit level of the costs of feed corresponded to the high unit costs of purchased feed. In the case of Malta and Spain, where home-grown feed was of marginal significance, purchased feed accounted for as much as $93-99 \%$ of the total value of feed, while in Sweden, Finland and Hungary this percentage was 67-69\%. Feed costs had the relatively lowest impact on income from milk production in farms in Romania (EUR 58/t) and Lithuania (EUR 80/t). In these countries, rearing of dairy cattle was, however, based more on home-grown feed (56-60\%), and less on purchased feed (40-44\%).

\footnotetext{
${ }^{3}$ Income from milk production is composed of the basic price, national aid and related payments.

${ }^{4}$ High income from milk production (EUR/t) in Finland results both from the high basic milk price (EUR 441/t), and from special aid (EUR 3/t) and national aid of up to EUR 80/t. In 2013, national aid for milk also played an important role in Portugal (EUR 18/t), Hungary (EUR 26/t), Latvia (EUR 24/t), Slovakia (EUR 15/t), Bulgaria (EUR 24/t) and Croatia (EUR 19/t).
} 
$\frac{7}{2}$

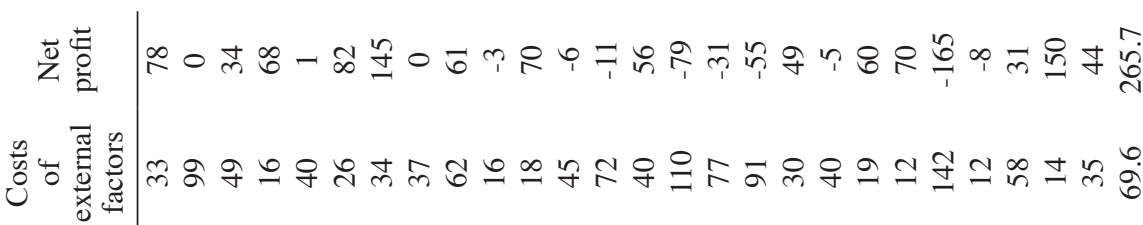
:

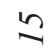

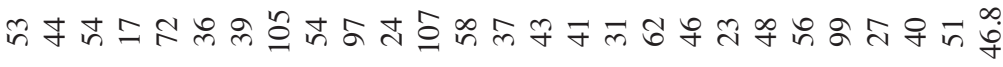

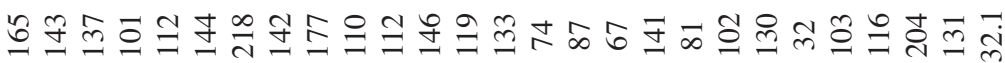

隹

.

离

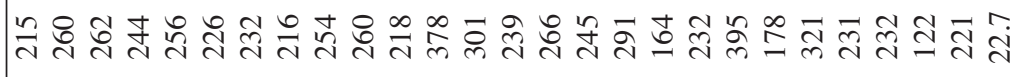

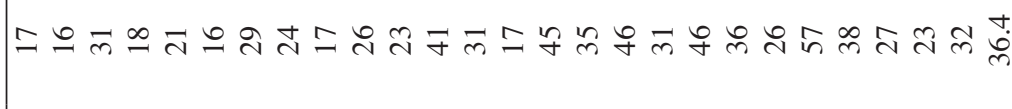

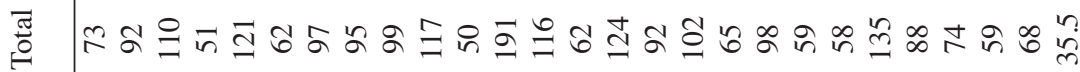

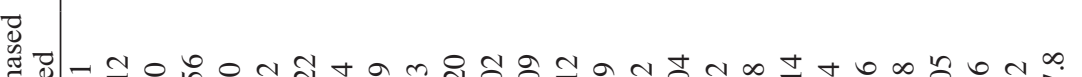

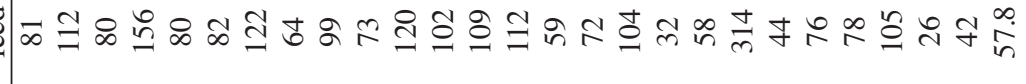

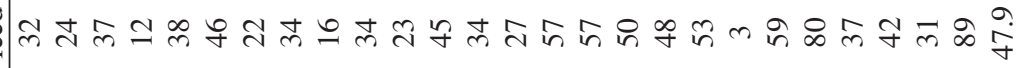

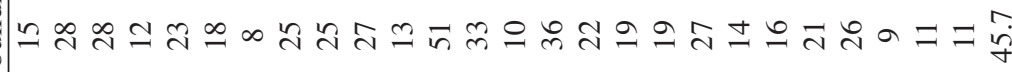

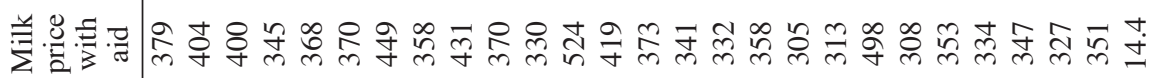

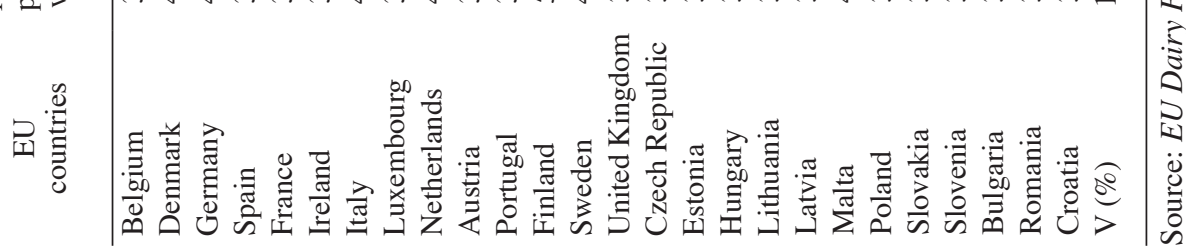


Another source of costs included in the analysis of the milk production margin are farming overheads. These costs quite strongly diversified the analysed community ( $\mathrm{V}=35.5 \%)$, their level varied in a wide range from 50-62 EUR/t in Portugal, Spain, Poland, Malta, Romania, Ireland and the United Kingdom to 120-191 EUR/t in France, Czech Republic, Finland and Slovakia. In addition, the data presented shows that such significant disparities are strongly associated with the level of unit energy costs, which in the vast majority of the countries (18) affected the total farming overheads to a very high extent.

Direct costs and farming overheads determine the level of operating costs of milk production. In 2013, unit operating costs (EUR/t) did not diversify strongly dairy farms of the EU countries $(\mathrm{V}=22.7 \%)$. However, given the extreme values (Table 4), we may observe that in Romania (EUR 123/t), Lithuania (EUR 164/t) and Poland (EUR 179/t), the costs were significantly lower than the average (EUR 246/t), while on farms in Slovakia (EUR 321/t), Finland (EUR 378/t) and Malta (EUR 396/t) they were much higher and exceeded their average EU level by $30-61 \%$.

In turn, more strongly than the operating costs dairy farms are diversified by the gross margin level $(\mathrm{V}=32.1 \%)$ determined by the unit milk price surplus $(\mathrm{EUR} / \mathrm{t})$ over the unit operating costs $(\mathrm{EUR} / \mathrm{t})$. However, the "ranking" of farms by gross margin is not fully consistent with their distribution by unit operating costs and results largely from the differences in milk prices. For example, in 2013 the lowest margin was characteristic of farms in Slovakia (EUR 32/t) which with very high operating costs (EUR 321/t) achieved the milk prices (EUR 353/t) at the level by about $10 \%$ lower than on average in the EU. The very high operating costs (EUR 378/t) are, however, also characteristic of farms in Finland. However, as a result of high national aid (EUR 80/t) Finnish farms achieved the highest unit income from milk production (EUR 524/t) in the EU, which significantly made up for their high operating costs and translated into the milk production margin (EUR 146/t) which was higher than on average. We should also pay attention to farms in Romania and Italy, which in 2013 year reached the highest and comparable gross margin level (EUR 204 and 218/t) and which basically differ (Table 4) in terms of herd sizes, cows' milk yield, feeding system, forage area productivity and labour productivity. The high milk production margin in these countries results from the different ratios of the operating costs to the milk prices. In Romania, the unit operating costs were only EUR 123/t, i.e. they were lower than on average by as much as 50\%, while the milk prices were at the level of EUR 327/t, i.e. by about $15 \%$ lower than on average in the EU. In turn, in Italy the level of the unit operating costs (EUR 232/t) differed little from the EU average. However, the milk price (EUR 449/t) achieved by Italian farms was relatively very high, as the higher prices were recorded only in Finland and Malta.

Despite the aforementioned differences based on the correlation analysis we may indicate a number of statistically significant and largely obvious relations 
between the margin and the above analysed elements of the account. In the light of the correlation analysis, the gross margin (EUR/t) is positively correlated with milk prices $(\mathrm{R}=0.300)$ and negatively with the cost components of the account, most strongly with the unit costs of home-grown feed $(\mathrm{R}=-0.416)$, unit energy costs $(R=-0.641)$ and total unit operating costs $(R=-0.420)$.

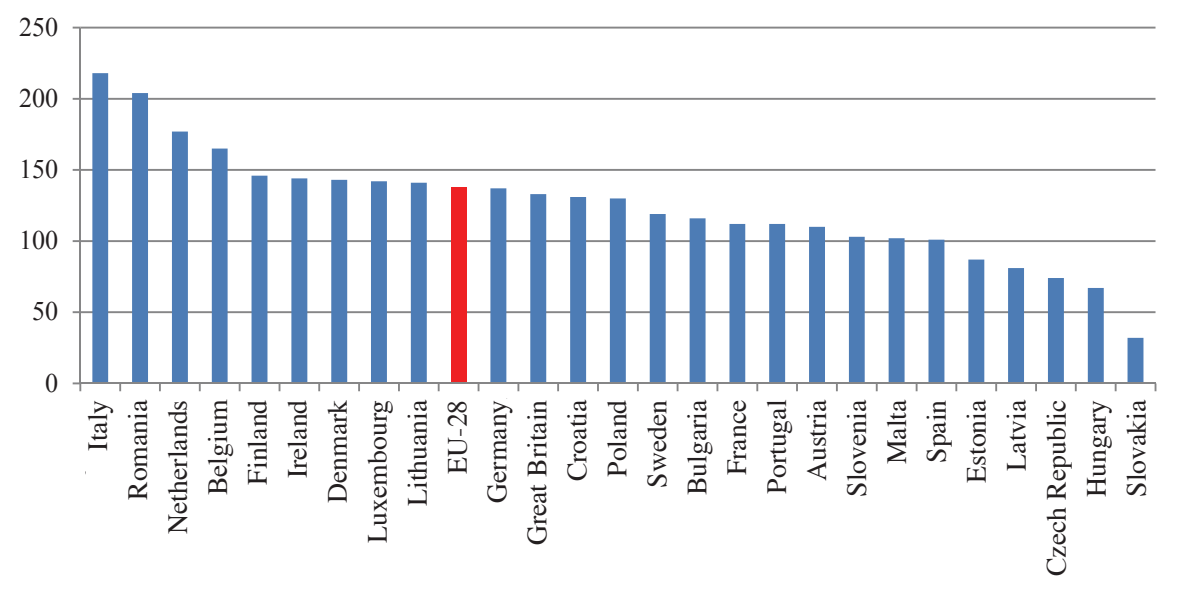

Fig. 6. Average gross margin (EUR/t) of milk production on dairy farms in the EU countries in 2013.

Source: own study.

Including the depreciation costs and the costs of external factors into the milk production margin account leads to estimating the net margin. The value of the variability index amounting to as much as $265 \%$ indicates clearly that the level of this margin category was very strongly diversified in the EU countries, several times more than that of the gross margin $(32.1 \%)$. The scale of disparities in this regards is clearly shown by the data contained in Table 4 . The analysis shows that in 2013 nine countries recorded a negative net margin level, in three countries it was close to zero, and in fourteen it was positive, but within a very wide range. The inability to generate profits was characteristic of farms in Slovakia, Czech Republic, Hungary and Estonia. On average, 1 tonne of milk produced in those farms generated a net loss between EUR 31 (Estonia) and EUR 165 (Slovakia). We can also talk about the inability to generate profits with reference to farms in Luxembourg, Denmark and France.

Although in their case no losses have been recorded, the average net margin level was close to zero. In turn, the positive net margin involves a strong diversification of its level. In Bulgaria, Germany, Croatia and Lithuania, 1 tonne of milk yielded a net profit of EUR 31-49, while in Italy and Romania, a net profit was as many as EUR 145-150/t. 
In the light of the correlation analysis, the net margin in 2013 was strongly correlated with the costs of external factors $(R=-0,762)$, and much less with the depreciation costs $(R=-0.286)$. A strong and negative relation between the net margin and the costs of external factors results largely from the costs of wages $(\mathrm{R}=-0.763)$. Those costs particularly strongly affected the net margin in Czech Republic, Estonia, Hungary and Slovakia, where the milk production was conducted using significant paid employment resources. On farms in these countries, the costs of wages accounted for as much as $72-87 \%$ of the value of the costs of external factors, while the EU average was about $40 \%$.

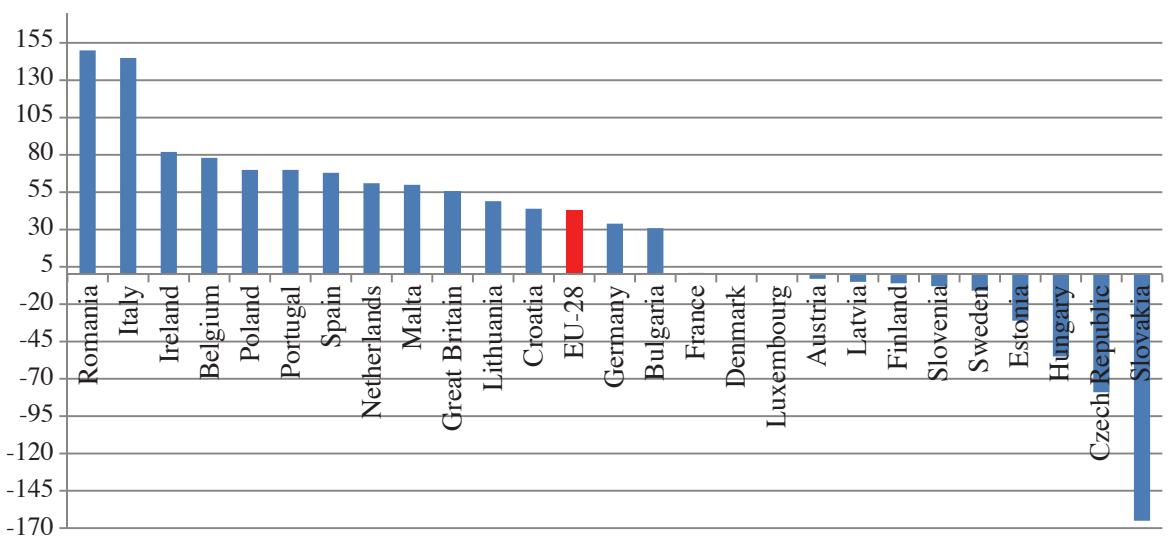

Fig. 7. Average net margin level (EUR/t) of the milk production on dairy farms of the EU countries in 2013.

Source: own study.

\section{Panel models of the milk production margin}

The above-presented technological and economic, price and cost parameters as well as their interrelations indicated, on the one hand, the strong diversification of their level on dairy farms of the EU countries and on the other - a number of cause-and-effect relations. In order to identify the strength and direction of the impact of these parameters on the milk production margin, the parameters of the panel regression models have been developed. In building the models, the data from the EU Dairy Farms Reports for 25 EU countries (without Croatia, Cyprus and Greece) $)^{5}$ for 2007-2013 was used (175 observations in a seven-year time series). In selecting the explanatory variables, the availability of the data and studies conducted by other authors were followed (cf: Mańko, 2007; Parzonko, 2013; Sass, 2004; Wójcik, 2010; Ziętara, 2003, 2010).

\footnotetext{
${ }^{5}$ The data for Cyprus and Greece is not published due to a sample too small (less than 15 farms), while the data for Croatia is available only for 2013.
} 
Table 5 describes the parameters of the panel regression models for the milk production margin, in which the explained variable $(\mathrm{Y})$ is the gross margin index (gross profit/income from milk production in \%) while the explanatory variables are: $X_{1}$ - forage area (ha), $X_{2}$ - number of cows (LU), $X_{3}-$ cows' milk yield $(\mathrm{kg}), X_{4}-$ milk price with aid $(E U R / t), X_{5}-$ costs of feed (EUR/t), $\mathrm{X}_{6}-$ herd restocking costs $(\mathrm{EUR} / \mathrm{t}), \mathrm{X}_{7}-$ costs of maintaining machinery and buildings $(E U R / t), X_{8}-$ energy costs $(E U R / t)$. The presented models properly explain the variability of the gross margin in the EU countries, while the $\mathrm{F}$ and Breusch-Pagan tests point to the purposefulness of using the panel estimators. In addition, in the light of the Hausman test, the model which is more efficient and thus better describes the variability of the gross margin is the fixed effects model.

Table 5

Panel models of the milk production gross margin

\begin{tabular}{|c|c|c|c|c|c|c|c|c|}
\hline \multirow[b]{2}{*}{ Variables } & \multicolumn{4}{|c|}{ Fixed effects model } & \multicolumn{4}{|c|}{ Random effects model } \\
\hline & coefficient & $\begin{array}{l}\text { standard } \\
\text { error }\end{array}$ & $\begin{array}{l}t \text {-Student } \\
\text { statistics }\end{array}$ & $\begin{array}{l}\text { significance } \\
\text { level } p\end{array}$ & coefficient & $\begin{array}{l}\text { standard } \\
\text { error }\end{array}$ & $\begin{array}{c}\text { statistics } \\
z\end{array}$ & $\begin{array}{l}\text { significance } \\
\text { level } p\end{array}$ \\
\hline Constant & 15.632 & 5.283 & 2.959 & 0.004 & 17.207 & 6.430 & 2.676 & 0.007 \\
\hline $\mathrm{X}_{1}$ & 0.149 & 0.023 & 6.576 & 0.000 & 0.114 & 0.019 & 5.746 & 0.000 \\
\hline $\mathrm{X}_{2}$ & -0.3592 & 0.053 & -7.586 & 0.000 & -0.3651 & 0.050 & -7.864 & 0.000 \\
\hline $\mathrm{X}_{2} \wedge 2$ & 0.0009 & 0.000 & 3.707 & 0.000 & 0.0011 & 0.000 & 4.566 & 0.000 \\
\hline $\mathrm{X}_{3}$ & 0.003 & 0.001 & 2.965 & 0.004 & 0.003 & 0.001 & 3.099 & 0.002 \\
\hline $\mathrm{X}_{4}$ & 0.188 & 0.008 & 23.36 & 0.000 & 0.190 & 0.008 & 24.44 & 0.000 \\
\hline $\mathrm{X}_{5}$ & -0.276 & 0.021 & -12.83 & 0.000 & -0.272 & 0.021 & -13.18 & 0.000 \\
\hline $\mathrm{X}_{6}$ & -0.440 & 0.125 & -3.516 & 0.001 & -0.404 & 0.121 & -3.336 & 0.001 \\
\hline $\mathrm{X}_{7}$ & -0.443 & 0.093 & -4.760 & 0.000 & -0.459 & 0.089 & -5.126 & 0.000 \\
\hline $\mathrm{X}_{8}$ & -0.556 & 0.085 & -6.527 & 0.000 & -0.569 & 0.081 & -6.983 & 0.000 \\
\hline & \multicolumn{4}{|c|}{$\begin{array}{l}\mathrm{LSDV} \mathrm{R}^{2}=0.975 \text {; in } \mathrm{R}^{2}=0.853 \text {, } \\
\text { Test for the differentiation of the absolute } \\
\text { term in groups: } F=28.71 \text { with } \\
p=9.09029 \mathrm{e}-043\end{array}$} & \multicolumn{4}{|l|}{$\mathrm{R}^{2}=0.961$} \\
\hline
\end{tabular}

Source: own calculations. 
From the analysis of the gross margin effects model, the following conclusions can be drawn:

- milk production gross margin is positively correlated with the size of the forage area $\left(\mathrm{X}_{1}\right)$; the increase in this area by one unit corresponded to the increase in the gross margin by about 0.15 percentage points;

- between the gross margin and the size of cow herd $\left(\mathrm{X}_{2}\right)$ there is a curvilinear relation, on a basis of which we may designate the theoretical minimum herd size; from the point of view of the gross margin, this minimum herd size is about 200 cows (LU);

- the gross margin level is positively affected by the increased cows' milk yield $\left(\mathrm{X}_{3}\right)$; the strength of impact of this factor was, however, not great, in fact, on average, the increase in the milk yield by $100 \mathrm{~kg}$ translated into the increase in the gross margin by only 0.3 percentage points;

- the gross margin is strongly associated to the prices obtained by producers of milk $\left(\mathrm{X}_{4}\right)$; the rise in the milk price by $1 \mathrm{EUR} / \mathrm{t}$ made the gross margin increase, on average, by 0.19 percentage points;

- the gross margin level was obviously negatively affected by the rise in the unit direct costs, i.e. feed $\left(\mathrm{X}_{5}\right)$, herd restocking $\left(\mathrm{X}_{6}\right)$, machinery and building upkeep $\left(\mathrm{X}_{7}\right)$ and energy $\left(\mathrm{X}_{8}\right)$; however, in terms of the strength of impact, the rise in the costs of feed reduced the gross margin to a much lower extent than other types of direct costs included in the model; the rise in the costs of feed $(E U R / t)$ by one unit reduced the gross margin, on average, by 0.27 percentage points, while for the remaining costs the scale of this reduction was about twice higher (0.44-0.56 pp).

Table 6 describes the parameters of panel regression models for the milk production margin, in which the explained variable $(\mathrm{Y})$ is the net margin index (net profit/income from milk production in \%) while the explanatory variables are: $X_{1}$ - forage area (ha), $X_{2}$ - number of cows (LU), $X_{3}$ - cows' milk yield (kg), $X_{4}-$ milk price with aid $(E U R / t), X_{5}$ - depreciation costs $\left(E U R / t\right.$ of milk), $X_{6}-$ remuneration costs $\left(E U R / t\right.$ of milk), $X_{7}$ - financial costs - interest (EUR/t of milk). As in the case of the gross margin, the presented models properly explain the net margin variability, and the tests applied also justify the purposefulness of using the fixed effects panel estimator.

The analysis of the parameters of net margin panel models with fixed effects leads to the following conclusions:

- milk production net margin is positively correlated with forage area $\left(\mathrm{X}_{1}\right)$; the increase in this area by one unit corresponded to the increase in the net margin by approx. 0.25 percentage points;

- there is a curvilinear relation between the net margin and the size of cow herd $\left(\mathrm{X}_{2}\right)$, which may be used as the basis for determining the theoretical minimum herd size; from the point of view of net margin increase, this minimum herd size is around 146 cows (LU); 
- in general, the net margin level is negatively affected by the increased cows' milk yield $\left(\mathrm{X}_{3}\right)$; however, the impact of this factor was not significant, since on average an increase in the milk yield by $100 \mathrm{~kg}$ translated into the margin reduction by only 0.5 percentage point;

- the net margin is strongly linked with prices obtained by producers $\left(\mathrm{X}_{4}\right)$; a rise in milk price by $1 \mathrm{EUR} / \mathrm{t}$ resulted in the net margin increase by, on average, approx. 0.18 percentage point;

- the net margin level was obviously negatively affected by the growth of unit depreciation costs $\left(\mathrm{X}_{5}\right)$, financial costs $\left(\mathrm{X}_{6}\right)$ and remuneration costs $\left(\mathrm{X}_{7}\right)$. However, from the point of view of the strength of impact, the net margin was particularly negatively affected by the remuneration costs. The rise in those costs by $1 \mathrm{EUR} / \mathrm{t}$ in fact reduced the net margin by 1.24 percentage points, while in the case of depreciation costs and financial costs the scale of this reduction was significantly lower (0.41 and $0.29 \mathrm{pp})$.

Table 6

Panel models net milk production margin

\begin{tabular}{ccccccccc}
\hline & \multicolumn{3}{c}{ Fixed effects model } & \multicolumn{3}{c}{ Random effects model } \\
\cline { 2 - 9 } Variables & coefficient & $\begin{array}{c}\text { standard } \\
\text { error }\end{array}$ & $\begin{array}{c}t \text {-Student } \\
\text { statistics }\end{array}$ & $\begin{array}{c}\text { significance } \\
\text { level } p\end{array}$ & coefficient & $\begin{array}{c}\text { standard } \\
\text { error }\end{array}$ & $\begin{array}{c}\text { statistics } \\
z\end{array}$ & $\begin{array}{c}\text { significance } \\
\text { level } p\end{array}$ \\
\hline Constant & 29.848 & 10.766 & 2.772 & 0.006 & 26.407 & 11.095 & 2.380 & 0.017 \\
$\mathrm{X}_{1}$ & 0.246 & 0.050 & 4.921 & 0.000 & 0.179 & 0.038 & 4.665 & 0.000 \\
$\mathrm{X}_{2}$ & -0.4967 & 0.109 & -4.543 & 0.000 & -0.4551 & 0.101 & -4.505 & 0.000 \\
$\mathrm{X}_{2} \wedge 2$ & 0.0017 & 0.001 & 2.747 & 0.007 & 0.0019 & 0.000 & 3.462 & 0.001 \\
$\mathrm{X}_{3}$ & -0.005 & 0.002 & -2.960 & 0.004 & -0.004 & 0.002 & -2.760 & 0.006 \\
$\mathrm{X}_{4}$ & 0.185 & 0.012 & 15.38 & 0.000 & 0.185 & 0.011 & 16.37 & 0.000 \\
$\mathrm{X}_{5}$ & -0.410 & 0.055 & -7.508 & 0.000 & -0.404 & 0.051 & -7.833 & 0.000 \\
$\mathrm{X}_{6}$ & -1.245 & 0.127 & -9.787 & 0.000 & -1.248 & 0.111 & -11.26 & 0.000 \\
$\mathrm{X}_{7}$ & -0.294 & 0.081 & -3.627 & 0.000 & -0.262 & 0.075 & -3.499 & 0.001 \\
$\ldots$
\end{tabular}

LSDV $\mathrm{R}^{2}=0.970$; in $\mathrm{R}^{2}=0.735$,

Test for differentiation of the absolute term in groups: $F=29.48$ with $p=1.334 \mathrm{e}-043$
$\mathrm{R}^{2}=0.938$

Breusch-Pagan test: $\chi^{2}=183.6$ with $p=8,07 \mathrm{e}-042$ Hausman test: $\chi^{2}=16.16$ with $p=0.040$

Source: own calculations. 


\section{Summary}

The EU dairy farm sector records a relatively marked increase in the size of herd cows, forage area and milk production. In addition, the development of production capacity of dairy farms is strongly associated with an increase in milk yield, forage area productivity and, what is particularly important, labour productivity. The dynamics of these processes varies in individual EU countries, hence the strong diversification of basic technological and economic parameters of dairy farms between the EU countries. Particularly clear differences concern the scale and effects of farm activities, measured by milk production volume, number of cows, labour resources, labour productivity, and cows' milk yield, as well as labour inputs.

However, the growth of production potential and productivity of dairy farms over the analysed period did not translate into a positive trend in gross and net margins. The milk production margin was subject to multidirectional changes, but generally followed a negative trend, mainly as a consequence of faster growth of production costs than milk prices.

The data from 2013 show that the highest net milk margin was recorded on farms in Romania and Italy, which essentially differ in terms of technological, economic and price-cost parameters. Compared to the average level of these parameters in the EU, dairy farms in Romania are characterised by the lowest scale of production measured by the number of cows and milk production volume as well as the lowest cows' milk yield and labour productivity. It results in very low operating costs, fixed costs and costs of external factors, which, despite relatively low milk prices, determine the high production margin. In Italy, rearing of dairy cattle is conducted on a much larger scale, which translates into a relatively high, when compared to the EU average, labour productivity and milk yield similar to the EU average. In addition, dairy farms in Italy achieved some of the highest milk prices in the EU, which, combined with operating costs, fixed costs and costs of external factors being significantly lower than the average, has a strong and positive impact on their milk production margin.

In a large number of the EU countries, milk production is unprofitable. The inability to generate profits as measured by the net profit was characteristic mainly of dairy farms in Slovakia and the Czech Republic. Their common feature is a very large scale of production measured by the number of cows and milk production volume and a significantly lower labour productivity than the EU average. The unprofitable milk production in these countries is also strongly associated with price and cost determinants. Dairy farms in Slovakia and the Czech Republic achieved milk prices lower than the EU average and incurred very high costs per production unit. Remuneration costs are a very important source of high cost intensity of milk production in these countries. Their level per tonne of milk was, respectively: $124 \mathrm{EUR} / \mathrm{t}$ (Slovakia) and $93 \mathrm{EUR} / \mathrm{t}$ (Czech Republic), while the EU average was only 17 EUR/t. 
From the point of view of the estimated regression model parameters, the variability of milk production margin depends largely on forage area, cow herd size, cows' milk yield, milk prices, energy costs and remuneration costs, while, to a relatively lower extent, on the cows' milk yield and feed costs. The identified causal relationships of these farms' characteristics with their margin were usually linear, except for cow herd size. The study results showed that, in theory, a margin increase requires a certain minimum cow herd size. In comparison with its average level in the EU, it is quite high and, in the case of net margin it amounts to approx. 150 cows per farm. 


\section{References}

Baltagi, B.H. (2005). Econometric analysis of panel data. $3^{\text {rd }}$ ed. London: John Wiley \& Sons Ltd.

Czyżewski, A., Staniszewski, J. (2016). Zastosowanie regresji panelowej dla oceny produktywności i dochodowości w rolnictwie krajów Unii Europejskiej po 2005 roku. Roczniki Naukowe Ekonomii Rolnictwa i Rozwoju obszarów Wiejskich, no. 3(103).

Economic accounts for agriculture. Retrieved from: http://appsso.eurostat.ec.europa.eu (access date: 15.04.2017).

EU Dairy Farms Report based on 2013 FADN data. (2016). European Commission Directorate-General for Agriculture and Rural Development, Brussels. Retrieved from: http:// ec.europa.eu/agriculture/rica/ (access date: 15.04.2017).

Farm structure survey 2013. Key variables: area, livestock (LSU), labour force and standard output (So) by type of farming (2-digit) and agricultural size of farm (UAA). Retrieved from: http://ec .europa.eu/eurostat/data/database (access date: 15.04.2017).

Franc-Dąbrowska, J. (2009). Praktyczne zastosowanie wybranych modeli panelowych do oceny sytuacji finansowej przedsiębiorstw rolniczych. ZN SGGW, Ekonomika i Organizacja Gospodarki Żywnościowej, no. 76.

Geise, A. (2013). Przestrzenno-czasowe modelowanie zmienności produkcji w sektorach mikro, małych, średnich i dużych przedsiębiorstwach w Polsce. Przegląd Statystyczny, no. 2.

Greene, W.H. (2003). Econometric analysis. $5^{\text {th }}$ ed. New Jersey: Macmillan Publishing Company.

Gruszczyński, M. (2002). Modele i prognozy zmiennych jakościowych w finansach i bankowości. Warsaw: Oficyna Wydawnicza SGH.

Kufel, T. (2007). Ekonometria. Rozwiązywanie problemów z wykorzystaniem programu GRETL. Warsaw: PWN.

Mańko, S. (2007). Wpływ wielkości stada i wydajności jednostkowej krów na koszty produkcji mleka. Roczniki Nauk Rolniczych, Series G, vol. 93, book 2.

Parzonko, A. (2013). Globalne i lokalne uwarunkowania rozwoju produkcji mleka. Warsaw: Wydawnictwo SGGW.

Parzonko, A. (2013). Konkurencyjność kosztowa polskich gospodarstw mlecznych na arenie europejskiej w perspektywie zmian polityki rolnej UE po 2014 roku. Zeszyty Naukowe SGGW, Problemy Rolnictwa Światowego, vol. 13, book 3.

Sass, R., 2004. Sytuacja ekonomiczna gospodarstw specjalizujących się w produkcji mleka. Roczniki Naukowe SERiA, vol. IV, book 1.

Wooldridge, J. (2002). Econometric analysis of cross section and panel data. London: The MIT Press.

Wójcik, A. (2010). Koszty i dochodowość produkcji mleka w gospodarstwach krajów europejskich. Roczniki Nauk Rolniczych, Series G, vol. 97, book 1.

Verbeek, M. (2004). A guide to modern econometrics. $2^{\text {nd }}$ ed. London: John Wiley \& Sons Ltd.

Ziętara, W. (2003). Efektywność produkcji mleka w wybranych gospodarstwach mlecznych w Polsce i w Unii Europejskiej. Przeglad Hodowlany, no. 2.

Ziętara, W. (2010). Koszty i dochodowość produkcji mleka w polskich gospodarstwach w latach 2006-2008. Roczniki Nauk Rolniczych, Series G, vol. 97, book 1. 
ZBIGNIEW GOEAŚ

Uniwersytet Przyrodniczy

Poznań

\title{
UWARUNKOWANIA RENTOWNOŚCI PRODUKCJI MLEKA W GOSPODARSTWACH MLECZNYCH KRAJÓW UNII EUROPEJSKIEJ
}

\begin{abstract}
Abstrakt
W artykule podjęto problematykę uwarunkowań rentowności produkcji gospodarstw rolnych wyspecjalizowanych w produkcji mleka. Badania przeprowadzono w układzie krajów Unii Europejskiej za lata 2007-2013 na podstawie cyklicznych danych publikowanych przez Komisje Europejska w raportach EU Dairy Farm Report. Rentowność produkcji mleka analizowano na podstawie szczegółowego rachunku przychodów i kosztów, który umożliwia wielowymiarowa ocene zdolności gospodarstw do generowania zysków $z$ produkcji mleka mierzona rentownościa brutto $i$ netto. Ponadto $w$ celu identyfikacji siły i kierunku wpływu wybranych charakterystyk techniczno-ekonomicznych, cenowych oraz kosztowych na rentowność produkcji mleka zastosowano metody regresji panelowej. W świetle parametrów regresji panelowej na zmienność rentowności produkcji mleka najsilniej wpływały: wielkość powierzchni paszowej, wielkość stad, wydajność mleczna krów, ceny mleka oraz koszty energii i koszty wynagrodzeń.
\end{abstract}

Słowa kluczowe: rentowność produkcji mleka, gospodarstwa mleczne, kraje UE, panelowe modele regresji.

Accepted for print: 16.10.2017.

Unless stated otherwise all the materials on the website are available under the Creative Commons Attribution 3.0 Poland license. Some rights reserved to the Institute of Agricultural and Food Economics - National Research Institute.

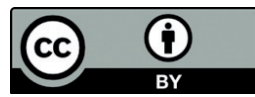

